\title{
Molecular-mass allocation of humic acids of soil under the influence of dung and composts
}

Tovstyi Yu.

NSC «A.N. Sokolovsky Institute of soil science and agrochemistry»

* Scientific supervisor - Doctor of Science of agrarian science le. Skrylnik

The purpose. To determine influence of dung and composts on its basis on molecular allocation and electrophoretic movability of humic acids, extracted from degraded chernozem by means of biochemical methods of fractionation. Methods. Field, laboratory, mathematical-and-statistical. Results. Influence of dung and composts on its basis on molecular allocation on size and electrophoretic movability of moleculas of humic acids, extracted from degraded chernozem by method of penetrating gel-filtering and electrophoresis in polyacrylamide gel is determined. Conclusions. Importation of compost (dung + husk) promotes formation of resistant against molding humic acids due to augmentation of size and charge of humic moleculas and stabilization of GK in soil.

Key words: humus, degraded chernozem, compost, humic acids, gel-filtering, electrophoresis, dung.

Study of the reactivity of humic acids (HA) in the natural environment, as well as their effective use in agriculture, is not possible without prior fractionation in relation to charge and size of molecules. The size and magnitude of the charge of molecules of the HA causes their mobility, stability, interaction with metal ions, minerals and organic compounds. Therefore, the study of the HA by means of fractionation methods (gel filtration and electrophoresis) allows with a minimum cost of forces and time to obtain a qualitative assessment of the nature of changes in the molecular organization of the HA under the influence of external human factors.

The study of the fractional composition of the HA fractionation methods were dealt with by DS Orlov, O. A. Trubetskoy, O. E. Trubetskaya, I. V. Perminov, E. Yu. Milanovsky, A. Piccolo, A. Nebbus and others. [1 10].

Objective - determine the effect of litter and compost on its basis on the molecular distribution and electrophoretic mobility of humic acids extracted from chernozem podzolizic by means of biochemical methods of fractionation.

Methods. The field short-term experiment is based on the field of research of the State Enterprise "DG" Grakivske "NSC" IGA of the name O. N. Sokolovsky "on the chernozem podzolizic. Scheme of experiment: 1 - without fertilizers (control); 2 - introduction of litter; 3 - composting (litter + straw); 4 - composting (litter + husk). Doses of fertilizer made up $10 \mathrm{t} / \mathrm{ha}$. Soil samples were taken at the end of August at depths of 0-30 cm out for DSTU 4287: 2007. Extraction of soil samples from soil samples was carried out for DSTU 7606: 2014. Fractionation of the HA electrophoresis was carried out in $10 \%$ polyacrylamide gel, which was applied to $0,15 \mathrm{mg}$ HA extracted from chernozem podzolizic. The molecular weight distribution of HA and fractions thereof was determined by gel filtration using a $1.5 \times 37 \mathrm{~cm}$ column filled with Sephadex G-50 gel, eluent $0.1 \mathrm{n}$ $\mathrm{NaOH}$. Detection of elution of humic acids was determined at wavelengths of $465 \mathrm{~nm}$.

Results. The data of gel filtration show that the distribution profile HA of the chernozem podzolizic after introduction of litter and compost on its basis in $0.1 \mathrm{n} \mathrm{NaOH}$ have one rather narrow, pronounced peak in the macromolecular region (Fig. 1). The position of the peak on the profile of the HA coincide, but differ in steepness of the maximum drop. The location of the peak proves not only the equality of the average molecular masses of the HA, but also the difference in their relative content. The maximum peak value is determined after the compost (litter + husk) is applied, the application of which contributes to the formation of 
resistant to the expansion of humus substances due to increasing the size and complication of the structure of molecules HA, which in turn helps to stabilize the HA in the soil.

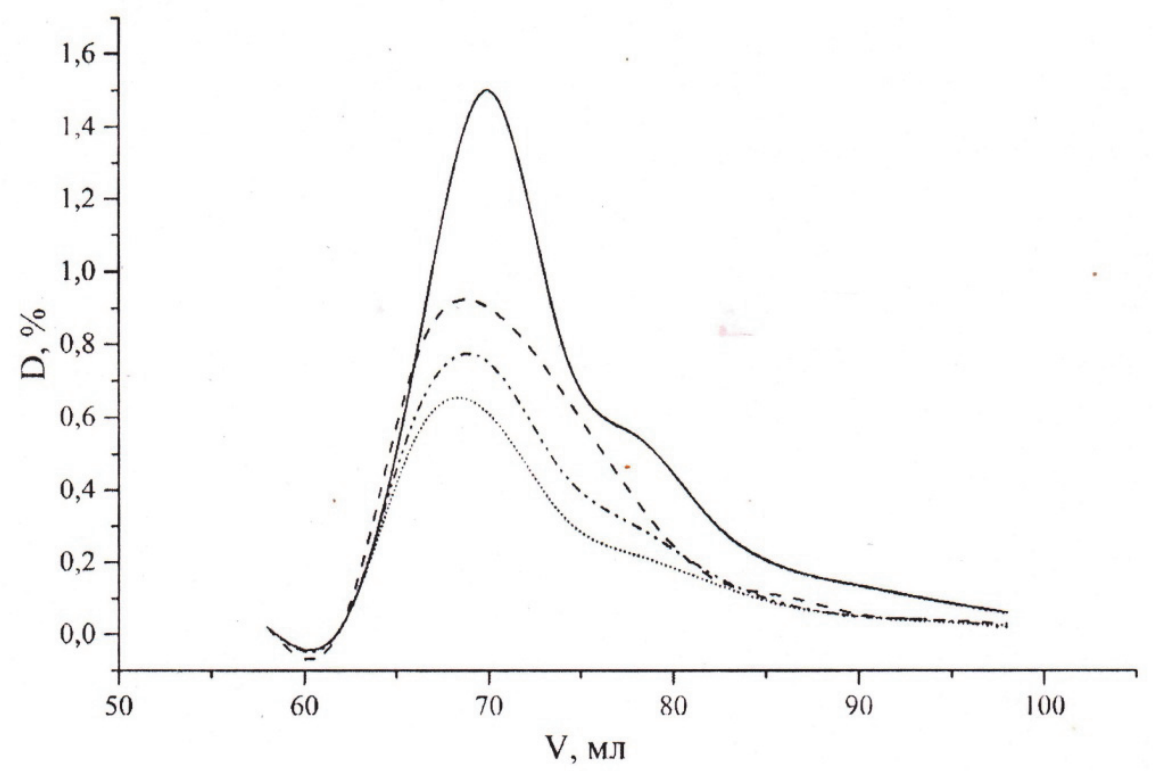

Fig. 1 Profile of the molecular distribution of the size of the molecules HA extracted from chernozem podzolizic under the influence of litter and compost on its basis (D, \% - absorption intensity at wavelength $465 \mathrm{~nm} ; \mathrm{V}$ - volume of elution, $\mathrm{ml})$ : $\cdots \cdots-$ - control; - - - - - litter; - — - compost (litter + straw); - compost (litter + husk)

After the introduction of the litter and compost (litter + straw), the peak displacement in the low molecular weight region is marked, indicating a decrease in the size and simplification of the structure of the molecules.

Extracted from chernozem podzolizic HA after the introduction of litter and compost on its basis, were fractionated by electrophoresis in $10 \%$ polyacrylamide gel (Fig. 2). Regardless of the type of organic fertilizer used, all of the HA were divided into four discrete, naturally painted electrophoretic zones, due to the presence of chromophore functional groups (polarized $\mathrm{C}=\mathrm{C}, \mathrm{C}=\mathrm{O}, \mathrm{COOH}, \mathrm{NH}_{2}$ and others) carrying charge: A - non-penetrating start in pores of $10 \%$ polyacrylamide gel; $\mathrm{B}$ - a narrow zone in the middle part of the gel; $C+D$ - zones located in the lower part of the gel and combined into fraction $C+D$ due to the proximity of their electrophoretic mobility (EM). The size of the molecules and EM are inversely proportional to the dependence: with the decrease in the size of the molecules of the HA increases its EM.

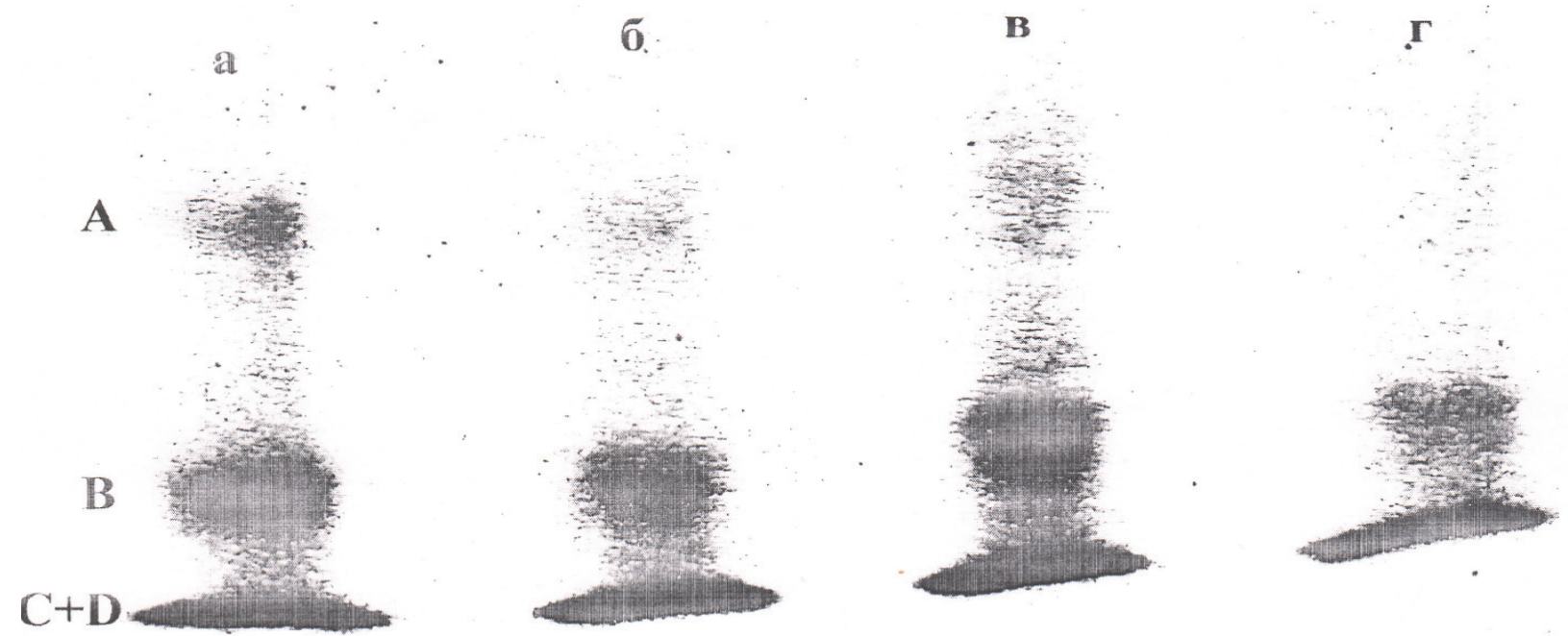

Fig. 2 Electrophoresis of GK extracted from chernozem podzolizic under the influence of the litter and compost on its basis in 10\% polyacrylamide gel $(A, B, C+D)$ electrophoretic zones in the matrix of polyacrylamide gel): a - control; 6 - litter; в - compost (litter + straw); a - compost (litter + husk) 
After the introduction of chicken manure and compost on its basis, the intensity of the fraction $A$ of humic acids increased in comparison with the control variant (Fig. 2), as a result of the formation of typical high molecular weight molecules due to the decomposition of organic fertilizers and newly formed humus molecules. The highest intensity of fraction $A$ is defined after the composting (litter + husk). The lowest intensity of fraction A was recorded in the control, where only the fractions A traces could be detected, indicating weak stability of the HA compared with the fertilized variants.

It is also necessary to note an increase in the intensity of the fractions B in the composition of the germs extracted from chernozem podzolizic after introduction of litter and compost on its basis, due to the reduction of EM and increase in the size of molecules in the general content of HA relative to the control variant.

Humic acids extracted from chernozem podzolizic are characterized by high electrophoretic mobility, and therefore most of them are concentrated in the $C+D$. The increase in the intensity of the $C+D$ fraction of HA extracted from chernozem podzolizic is determined after the introduction of chicken manure and compost on its basis. The most intense band in the $C+D$ zone is defined after the composting (litter + husk).

The results of the determination of EM are consistent with the data of gel filtration, which indicate an increase in the size and surface charge of humic chernozem podzolizic under the influence of compost (litter + husk).

\section{Conclusions}

Investigation of the molecular distribution of humic acid extracts extracted from chernozem podzolizic after introduction of litter and compost on its basis indicate that the use of compost (litter + husk) contributes to the formation of resistant to the expansion of humus substances due to increasing size, complication of the structure and reduction of electrophoretic mobility of molecules HA, which helps to stabilize humus substances in chernozem podzolizic.

\section{Bibliography}

1. Nebbioso A., Piccolo A., Lamshoft M., Spitellerb M. (2014). Molecular characterization of an endresidue of humeomics applied to a soil humic acid. RSC Adv. № 4. P. $23658-23665$.

2. Nebbioso A., Piccolo A. (2013). Advances in humeomics: Enhanced structural identification of humic molecules after size fractionation of a soil humic acid. Analytica Chimica Acta. № 7. P. 77 - 90.

3. Nebbioso A., Vinci G., Drosos M., Spaccini R., Piccolo A. (2015). Unveiling the molecular composition of the unextractable soil organic fraction (humin) by humeomics. Biology and Fertility of Soils. № 5. P. $443-$ 451.

4. Trubetskaya O., Trubetskoj O., Richard C. (2014). Hydrophobicity of electrophoretic fractions of different soil humic acids. Soil and Sediment. № 4. P. 292 - 297.

5. Rishar K., Giyo Zh., Aguer Zh., A. ter Halle, Trubetskaya O.E., Trubetskoy O.A. (2008). Rol fraktsionirovaniya pri izuchenii fotohimicheskih svoystv gumusovyih veschestv. Ros. him. ob-va im. D.I. Mendeleeva. № 1. S. 107 - 113. [In Russian].

6. Milanovskiy E.Yu. (2009). Gumusovyie veschestva pochv kak prirodnyie gidrofobno-gidrofilnyie soedineniya. Moskva: GEOS. 186 s. [In Russian].

7. Orlov D.S. (1974). Gumusovyie kislota pochv. Moskva: Izd-vo MGU. 333 s. [In Russian].

8. Zavarzina A.G., Vanifatova N.G., Stepanov A.A. (2008). Fraktsionirovanie giminovyih kislot po otnositelnoy gidrofobnosti, razmeru i zaryadu metodom vyisalivaniya. Pochvovedenie. № 12. S. 1466 1474. [In Russian].

9. Ilina A.A., Maslov S.G., Rodina N.V. (2007). Issledovanie sostava natrievyih i ammonievyih guminovyih kislot. Himiya rastitelnogo syirya. № 2. S. 85 - 88. [In Russian].

10. Skrilnik E.V. Maklyuk O.I., Poplrniy M.A. (2017). Vpliv fermentativnoyi aktivnostl chornozemu tipovogo na sklad I gldrofobno-gldrofllnl vlastivostl gumlnovih kislot za rlznogo obrobltku Gruntu. VIsnik agrarnoyi nauki. Kyiv. № 5. S. 11-16. 